\title{
Historical Path of Japanese Militarism
}

\author{
Ying Wang ${ }^{1}$,Yaochun $\mathrm{Hai}^{2}$ \\ ${ }^{1}$ Engineering and Technical College, Chengdu University of Technology, Leshan, 614000, China \\ ${ }^{2}$ Yangtze Normal University, Chongqing, 408100, China
}

Keywords: Japanese militarism, Historical reason, Political factor

\begin{abstract}
Recently, the right-wing forces of Japan have continuously beautified the Japanese invasion during the World War II, denied history, developed the militarism and make reactionary speeches under the protection of America, greatly hurting the feelings of the invaded nations in Asia and destroying the peace and stability in Asia. Militarism is the historical tradition of the Japanese nation, after the trauma of war, Japan still make the daydreaming of militarism by ignoring the theme of peace and development in the world, which has deep historical reasons. In this paper, the author analyzes the historical reasons for Japan to visit to the Yasukuni war shrine, modify constitution and expand military forces from the natural geographical environment, national cultural characteristics and political fighting.
\end{abstract}

\section{Foreword}

At 11:30 on December 26, 2013, the Japanese prime Shinzo Abe visited to the Yasukuni war shrine where 14 Class A war criminals are enshrined, which aroused the strong protest of the Asian people immediately, and this behavior was another action to destroy the world peace after the Diaoyu Island incident, indicating that the right-wing forces in Japan have been further developed, and militarism rises again from ashes in Japan. After the World War II, great changes occurred to the world pattern, the Nazi Germany was thoroughly destructed under the encirclement of the world anti-fascist forces. At present, Germany has a good apology attitude in front of history and the German nation has a heavy sense of guilt for the war of human extinction, and its attitude toward the war is accepted by the whole world. But why does Japan, as the fascist force in Japan not regret after the World War II but to hurt the feelings of the Asian people for repeatedly? In this paper, we will have a discussion from the spirit of worshipping war of the Japanese nation to the peal of militarism in the World War II and to America's sheltering of Japanese war criminals after the World War II.

\section{Breeding of militarism by historical and geographical environment}

The geographical condition is the material base for the survival and development of human beings, both the physical and mental development of the human beings must rely on the materials base, and the geographical environment directly decides the formation of a national spirit to a great extent. To deep understand the formation of Japanese militarism, we must analyze the formation and development history of the Japanese national spirit from the national geographical environment of Japan. Japan is an island country, with a small national territorial area of 373,800 square kilometers in total, only equivalent to $1 / 26$ of the national territorial area of China. In such a small area, the available resources are also limited. Japan is a mountainous country, causing that the available cultivated land for agriculture is only $508 \mathrm{ha}$, about $13 \%$ of its national territorial area, with per capita cultivated land area in a low level in the world. In terms of mineral resources, although there are many varieties, it is seriously short of petroleum and coal resources as the life line for industrial development and above $90 \%$ of the energies for industrial development must rely on import. In addition, Japan is a famous country of earthquake, with land located in the circum-Pacific seismic belt. The frequent earthquake has a great impact on people's production and life. Facing the small land area and the severe environment of many natural disasters, the Japanese nation has been strongly thirst for land resources. During the World War II, Japan first occupied Northeast China with fertile 
land and rich resources and began the large-scale immigration scale. A series of invasion activities in the Southeast Asia were also for the purpose of plundering the resources. The so called great-East Asia War was a war of plundering land and resources in nature. In Japan, the militarism is also influenced by the special geographical environment of the island country. The modern development history of the world can be said to be from the ocean, and countless of empires rose from the Great Navigation Epoch, like Spain, Portugal, Holland, Britain, and the common characteristic in rising of these empires was war and plundering. As an island country, Japan also has this character, under the condition that its navigation technology was somewhat developed, Japan began the foreign invasion war, in 1592 and 1597, in the Sengoku of Japan, Lose Lazire invaded the Korean Peninsula for twice, and in the Ming Dynasty of China, the Japanese pirates dominated by the ronins had been active in the southeast coastal area of China.

The Marxist philosophy holds that land is the source of all productions and survivals, which both provide labor means and labor materials, and also the place of living for the community, i.e. the base of community. Restricted by the natural conditions for a long time, Japan as formed a consciousness of expansion contrary to the natural environment and worships military forces in order to expand the survival space. In this aspect, an independent social level "samurai" has to be mentioned, as a tool for the ruling group to strive for the territory, the samurai reflects the Japanese nation's spirit of worshipping war. During the war, Japan formed groups consisting of samurais. At the end of the 12th century, the samurai leader Minamoto Yoritomo acted as the "general of invasion", and created Kamakura shogunate to lead the military and political affairs of the whole nation. For a long time (1192-1868), Japan had been riled by the samurais. In the film The Last Samurai, the spirit of samurai was concluded the good moral characters of "braveness, loyalty and righteousness", but the samurais still reflect the nature of cruelty, ignorance and craziness. The Samurai spirit had a deep influence on the Japanese, making them form a national character of cruelty and being fond of fighting. Such spirit had always been supporting the Japanese masses to launch invasion activity to Asia. Although the arrogance of Japan was suppressed after the World War II, with the development of economy and change of the international situation, Japan has begun its daydream of becoming a power again.

\section{Process of peak of Japanese militarism}

Under the influence of the traditional spirit of worshipping war and militarism, at the end of the 19th century and beginning of the 20th century, the militarism of Japan reached the peak. The Great Navigation Epoch from the 15th to the 17th centuries, also called the Epoch of Great Geographical Discovery promoted the rapid development of European capitalism, and many European countries seized the opportunities to occupy a large area of colonies and carved up the world. In 1853, Matthew Perry, commander of American East Indian Fleet led four warships to force Japan to open its gateway closed for more than 200 years, making Japan feel the great gap with the western world. Taking advantaging of the opportunity that the imperialism was busy in carving up China, Japan carried out the capitalism reform from top to bottom, and established Meji government and determined the constitutional monarchy in 1868 and began the industrial development and developed education greatly, making great progress. The development of Japanese modernism promoted Japan to take the road of militarism. In such world order dominated by the greed of the capitalism, Japan was influenced by many domestic and foreign factors and made great efforts to develop militarism, sowing the seeds for the war of overall aggression to China and the Pacific War.

Marx's evaluation to the capitalism was to pursue the benefit maximally, and in such an age when the capitalism dominated the world, there was no fairness and rule at all. The development of capitalism was often built on the cruel exploitation to the masses. The capitalist countries developing rapidly were all based on the squeezing to the proletariats and the resources of other countries, for example the plundering activities of Britain in Africa and Indian, Spain in America, France and America in the Southeast Asia. These western capitalist countries were influenced by the humanistic thought in the Renaissance, and the domestic suppressed proletariats would resist the squeezing of the capitalists. But such situation was changed distortedly in Japan, the specialty of Japan was the 
position of the Mikado as the spiritual leader, when suppressed, the Japanese proletariats were thirst to establish an autocratic regime ruled by the Mikado, and some youths with ability and thought at the bottom of the society, while bitterly hating the unfair social system, placed their hopes on the change of social status by establish an autocratic government, developing military dictatorship and militarism and foreign aggression. In 1855, the great ideologist Fukuzawa Yukichi with influence in Japan pointed out in the book Leaving Asia Theory that "compared with China and Korea, Japan has the advantages of getting rid of the corrupt customs of Asia and introducing the western civilization." "To achieve success, Japan should not wait for the enlightenment of the neighboring countries to jointly make Asia rise hesitantly, but should leave Asia and make progress with the western civilization; and for the treatment with China and Korea, Japan should not be too kind due to the relation of neighboring countries, but should treat them like the westerners", which did not only reflect the contempt of Japan to other Asian countries, but also reflected its infinite mission of "Joint Prosperity of the Great East Asia”. At that time, many parties and assemblies themed patriotism appeared in Japan, promoting Japanese ruler to establish the dictatorship regime of militarism in order to stabilize the domestic situation. In this process, the international situation also fueled the military expansion of Japan, the long-time capitalist countries have almost carved up the whole world completely, as an emerging capitalist country, Japan had only very limited world market to occupy, which was very difficult to meet the development demand of Japan. In order to gain more benefits, Japan launched Japan-Russia War in Northeast China and actively participated in the World War I, but only to get the leftovers, and did not change its international status in nature, which made the Japanese nation with a strong desire of expansion and strong sense of self-respect very disappointed. Each level of the Japanese society regarded the western capitalist countries as enemy, and also generated the urgent desire of invading the colonies of the western countries. The bottom-level masses of Japan even mistakenly thought that the cruel invasion of the Asian colonial powers was the liberation movement, such wrong understanding utilized by the ruling class, and even today, many Japanese masses still do not know the ugly truth of invasion. The thirst of the Japanese masses to the rising of nation was used by the militarists who wanted to gain the benefit, and combined with the crazy invasion, finally making the masses' pursuit to the social equality become the craziness to invasion. Such transformation from the leftism to the extreme right become a uniquely strange historical phenomenon in Japan.

\section{Reasons for the renaissance of modern Japanese militarism}

The main factors for the renaissance of modern Japanese militarism is completely dominated by America. The management policy launched by America after Japan's surrender created conditions for the renaissance of Japanese militarist forces, which can be discussed from the surrender process of Japan. After Japan suffered from great failure in the Chinese battlefield and Pacific battlefield, there was no resistance movement appearing in Japan like in Italy and Germany. As America suffered from the suicide attack like kamikaze in the war with great loss, after dropping two atom bombs to the mainland of Japan, America still conservatively estimated that it could occupy Japan completely after a loss of 500,000 military troops. On one hand, America did not want the Soviet Union to interfere with the Japanese affairs in case of separation like Germany, and on the other hand, it did not want to suffer great loss, and when Japan surrendered, American intentionally avoided discussing the decision on abolition of Tennoism with other countries, and helped Japan reserve the militarism and the Mikado symbolizing the military dictatorship, and such action was to shield the militarists, sowing the seeds for the development of the right-wing forces of Japan in the future.

After the World War II was the period of Cold War (1947-1991), during this period, in order to cultivate Japan into the forward position of anti-communism, America further protected a group of war criminals and did not expose and criticize the crime of war, but used the war base of Japan to launch war to the socialist countries. During the Korean War and Vietnam War, the military industry of Japan was recovered, and a group of orders of war materials in combination with the economic recovery policy promoted the rapid development of Japanese economy. Japan emphasized education 
very much, while cultivating talents, it also beautified the aggressive war. Due to the great use value, America did not want to interfere with Japan, causing that the militarist thought communicate and develop in the Japanese society. By virtue of the international situation of Cold War, Japan achieved rapid development in economy, at the end of the 1960s, Japan became the second largest economic entity in the world, and its military forces were also reserved to a certain extent, becoming the necessary conditions for the right-wing forces to modify the constitution and expand troops.

After the Cold War, the Soviet Union was decomposed and China became the largest socialist country in the world. In recent years, with the rapid development of Chinese economy, China has become the main rival in the eye of America, and Japan, as the first island chain subject for America to contain China and with a certain national contradiction with China, becomes an important piece for America to contain China. The purpose of America to use Japan to contain China, destroy the stability in Asia and suppress the development of China is taken as the tool for the Japanese right-wing forces to develop militarism again. From 1951, by ignoring the opposition of the Asian people, 13 primes of Japan have visited to the Yasukuni Shrine for many times, wiling to act as the cat's pawn of America to destroy the development environment of America. In 1951, the Japanese prime Shigeru Yoshida visited to the Yasukuni Shrine for the first time, and it was he who sign the Japan-US Security Treaty with America, the nature of which is that America takes Japan as the military colony to interfere with the Asian countries. In 2012, America decided to take Diaoyu Island as the interference scope of the security treaty, which, in combination with various bad deeds of Japan in history, becomes a new stage for Japan to develop militarism, threatening China greatly.

\section{Conclusion}

The Japanese militarism tradition has a long history, and if it is not envisaged, Japan would follow the old disastrous road in history. Currently, the strengthening of right-wing forces in Japan has to arouse the concern and alerting of the Asian countries. We must make full preparation for the development of Japanese militarism and unite the Asia countries to urge Japan to envisage the history, correct the wrong actions of modifying teaching materials, visiting to the Yasukuni Shrine coveting the Diaoyu Island, recognize the real intention of America to destroy the peaceful and stable environment of Asia and urge Japan to take the road of peaceful development.

\section{References}

[1] Liu Tinghua, Historical Origin for Increasingly Rampant Japanese Militarism Trend [J] Military History, 2013 (01)

[2] Wei Juan, Influence of Japanese Fascists during the Showa Period on the Japanese Militarism [J], Youthful Days, 2013 (07)

[3] Qian Lu, Sticking, Surpassing and Deformity-Constitution of Japanese Samurai Spirit [J] Research on Japanese Issues, 2013 (03)

[4] Zhang Xiaomin, On New Militarism of Japan [J], Journal of Dali University, 2013 (05)

[5] Shi Shaobo, Japanese Militarism under the Vision of Kiyoshi Inoue [J], Yangtze Tribune, 2013 (08)

[6] Wei Yanli, Immigration Invasion of Japanese Militarism [J], Historical Annals of Heilongjiang, 2012 (07)

[7] Zhang Baoyin, Xu Zhuangzhi, Memory of Witnesses, Revealing of Historical Fact of "Exploration Group" in Japanese Aggression against China [J] Sichuan Party Construction: Urban Edition, 2011 (09) 